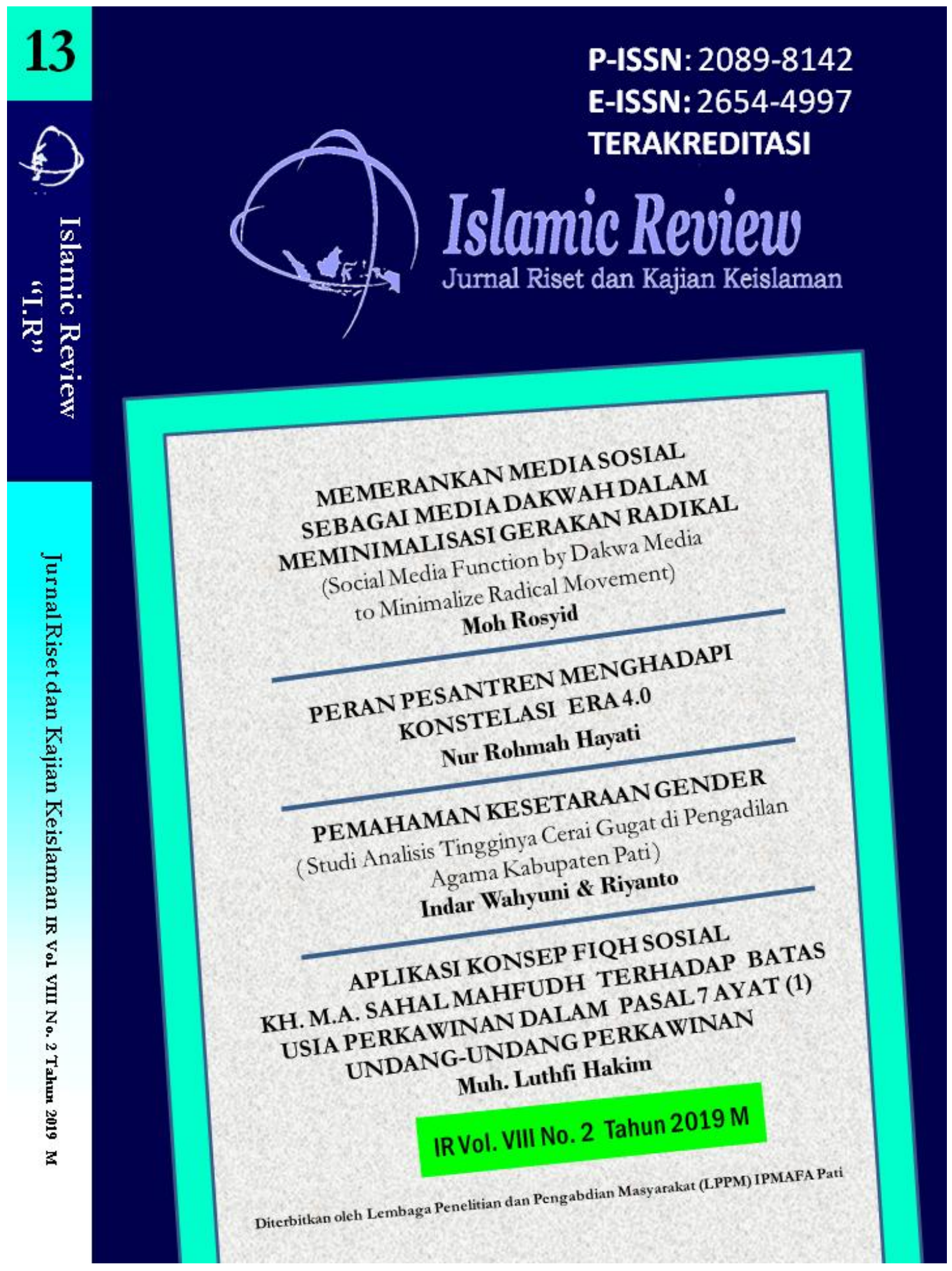


P-ISSN: 2089-8142

E-ISSN: 2654-4997

TERAKREDITASI

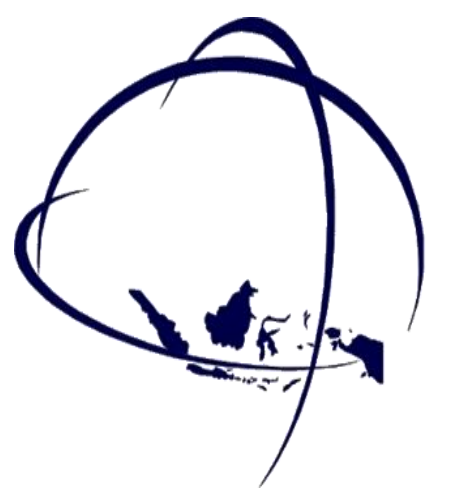

Islamic Review Jurnal Riset dan Kajian Keislaman

IPMAFA PRESS 


\section{Susunan Redaksi \\ ISLAMIC REVIEW}

'IR'

Jurnal Riset dan Kajian Keislaman

Intitut Pesantren Mathali'ul Falah (IPMAFA)

Pati, Jawa Tengah

\section{Penanggungjawab}

Abdul Ghaffar Rozin (Rektor IPMAFA Pati)

\section{Editorial Board}

Syamsul Ma'arif, (Scopus ID 57196279085) Universitas Islam Negeri Walisongo, Semarang Khoirun Niam, (Scopus ID: 57200652037; h-index: 1) Universitas Islam Negeri (UIN) Sunan Ampel, Surabaya

Moch Nur Ichwan, (Scopus ID: 39361628400; h-index: 2) Sunan Kalijaga State Islamic University, Yogyakarta

Al makin, (Scopus Author ID: 38162109000, h-index: 2) Sunan Kalijaga State Islamic University, Yogyakarta

Andar Nubowo, Nahyang Technological University, Singapore

Muhammad Syafiq, Nahyang Technological University, Singapore

Muhyar Fanani, Universitas Islam Negeri Walisongo, Semarang

Dimyati, Institut Pesantren Mathali'ul Falah Pati

Agus Waluyo, Institut Agama Islam Negeri Salatiga

Nur Said, Institut Agama Islam Negeri Kudus

\section{Editorial Team}

Editor In-Chief

Managing Editor

Editor

Asisten Editor

: A. Zaenurrosyid, Institut Pesantren Mathali'ul Falah Pati

: M. Sofyan Al-Nashr, Institut Pesantren Mathali'ul Falah Pati

: Isyrokh Fuadi, Institut Pesantren Mathali'ul Falah Pati

: Nur Khoiriyah, Institut Pesantren Mathali'ul Falah Pati

: Ahmad Dalhar Maarif, Institut Pesantren Mathali'ul Falah Pati

\section{Penerbit}

: Arina Ulfatul Jannah, Institut Pesantren Mathali'ul Falah Pati

IPMAFA Press

Frekuensi terbit 2 kali setiap 6 bulan sekali (April dan Oktober)

\section{ALAMAT REDAKSI}

Lantai 1 Kampus IPMAFA, Jl. Raya Pati-Tayu KM 20, Purworejo Margoyoso Pati Jawa Tengah 59154, Telp.: 0295-5501999, Hp: 085743602 083, Fax: 0295-4150081, Website: http://journal.ipmafa.ac.id/, Email: islamicreview@ipmafa.ac.id

Redaksi mengundang para pembaca agar berpartisipasi aktif untuk memberikan kontribusi artikel baik hasil pemikiran, penelitian maupun book review pada edisi selanjutnya. Dengan demikian silaturahmi pemikiran akan tetap berlangsung. 
DAFTAR ISI

MEMERANKAN MEDIA SOSIAL SEBAGAI MEDIA DAKWAH DALAM MEMINIMALISASI GERAKAN RADIKAL (Social Media Function by Dakwa Media to Minimalize Radical Movement)

Mob Rosyid. $135-160$

PERAN PESANTREN MENGHADAPI KONSTELASI ERA 4.0

Nur Rohmah Hayati. $161-174$

PEMAHAMAN KESETARAAN GENDER ( Studi Analisis Tingginya Cerai Gugat Di Pengadilan Agama Kabupaten Pati )

Indar Wabyuni \& Riyanto. $175-206$

APLIKASI KONSEP FIQH SOSIAL KH. M.A. SAHAL MAHFUDH TERHADAP BATAS USIA PERKAWINAN DALAM PASAL 7 AYAT (1) UNDANG-UNDANG PERKAWINAN

Muh. Luthfi Hakim. $207-234$

KONSEP MASHLAHAH AL-AMMAH DALAM PERSPEKTIF FIQH SOSIAL KH. MA. SAHAL MAHFUDH

Zahrotun Nafisab \& Arif Chasanuddin $235-258$

تقويم تعليم اللغة العربية (دراسة الاختبرات اللفوية)

Nibayatus Sa'diyah, Risalatul Muawanah, Zakiyah Isnawati. $259-276$

BOOK REVIEW: MENGEKANG EMOSI NEGATIF KUNCI MERAIH KEDAMAIAN DALAM HIDUP

Ab Dalhar Muarif $277-281$ 


\title{
PERAN PESANTREN MENGHADAPI KONSTELASI ERA 4.0
}

\author{
Nur Rohmah Hayati \\ Dosen STAINU Purworejo Jawa Tengah \\ Email: nur.rohmah.hayati@gmail.com
}

\begin{abstract}
Indonesia is currently entering the era of the Industrial Revolution 4.0. Mid-century (digital revolution) was marked by a combination of technology and blurring of physical, digital space lines. Changes in the world in the era of the Industrial revolution which is so fast certainly provide demands for progress. Islamic boarding schools or Islamic boarding schools are one of the Islamic education in Indonesia. The reform and reconstruction of Islamic education and its institutions seems to need to be carried out immediately, especially looking at the development of the world which requires that every Islamic education institution be it Islamic boarding schools or madrasas to continue to improve themselves if they do not want to be abandoned by their interested ones. The inclusive attitude of Islamic education in this context is very necessary. inclusiveness becomes very important given that however, Islamic education institutions cannot isolate themselves from the dynamics that occur outside themselves. Era of Industrial Revolution 4.0 (hereinafter: Era 4.0) has an unimportant impact. It affects all aspects of human life. Included in this case is education. This era was marked by the increasingly central role of cyber technology in human life. The challenges of the Industrial Revolution 4.0 era are very complex. Not to mention in the world of education, all have already converted in the digital world. If in the past it was quite a manual, old-fashioned, primitive system, now everything must be completely cyber. Examples of e-library (digital library), e-learning (digital learning), e-books (online books).
\end{abstract}

Keywords: Boarding School, Constellation, Era 4.0. 
Nur Rohmah Hayati

\begin{abstract}
Abstrak
Indonesia saat ini memasuki era Revolusi Industri 4.0. Pertengaban abad ini (revolusi digital) ditandai perpaduan teknologi dan mengaburkan garis ruang fisik, digital. Perubahan dunia di Era revolusi

Industri yang begitu cepat tentu memberikan tuntutan kemajuan. Pesantren atau Pondok. Pesantren adalah salah satu pendidikan Islam di Indonesia. Reformasi dan rekonstruksi terhadap pendidikan Islam beserta lembaga-lembaganya tampaknya perlu segera dilakukan, terutama mencermati perkembangan dunia yang mengharuskan setiap lembaga pendidikan Islam entah itu pesantren atau madrasab untuk. terus berbenah diri kalau tidak ingin ditinggalkan oleh peminatnya. Sikap inklusif dari pendidikan Islam dalam konteks ini sangat diperlukan. inkIusivitas menjadi sangat penting mengingat bahwa bagaimanapun, institusi pendidikan Islam tidak mungkin mengisolisasi diiri dari dinamika yang terjadi diluar dirinya. Era Revolusi Industri 4.0 (selanjutnya: Era 4.0) membawa dampak yang tidak sederhana. Ia berdampak pada seluruh aspek kehidupan manusia. Termasuk dalam hal ini adalah pendidikan. Era ini ditandai dengan semakin sentralnya peran teknologi cyber dalam kehidupan manusia. Tantangan era Revolusi Industri 4.0 kompleks sekali. Belum lagi di dunia pendidikan, semua sudah berkonversi di dunia digital. Jika dulu cukup sistem manual, kuno, primitif, saat ini semua harus serba siber. Contobkan e-library (perpustakaan digital), e-learning (pembelajaran digital), e-book (buku online).
\end{abstract}

Kata Kunci: Pesantren, Konstelasi, Era 4.0.

\title{
A. Pendahuluan
}

Indonesia saat ini memasuki era Revolusi Industri 4.0. Pertengahan abad ini (revolusi digital) ditandai perpaduan teknologi dan mengaburkan garis ruang fisik, digital. Era Revolusi Industri jilid 4.0 ini semakin sedikit aktivitas terikat secara fisik pada lokasi geografis, batas-batas semakin tipis. Selain itu sebitu cepatnya berita dan teknologi berkembang, sehingga menggeser peranan manusia di berbagai sektor kehidupan. Ada enam prinsip desain Industri 4.0, mulai dari interoperability, virtualisasi, desentralisasi, kemampuan real time, berorientasi layanan dan bersifat modular. Revolusi Industri 4.0 dapat diartikan sebagai era industri, di mana seluruh entitas di dalamnya dapat saling 
berkomunikasi secara real time kapan saja dengan berlandaskan pemanfaatan teknologi internet dan CPS guna mencapai tujuan tercapainya kreasi nilai baru ataupun optimasi nilai yang sudah ada dari setiap proses di industri. ${ }^{1}$

Perubahan dunia di Era revolusi Industri yang begitu cepat tentu memberikan tuntutan kemajuan. Kemajuan suatu bangsa tergantung dari kualitas pendidikan yang diterima warganya. Pendidikan merupakan faktor utama dalam membentuk sumber daya manusia yang berkualitas, dengan demikian dapat memajukan setiap lini kehidupan sehingga mendorong signifikansi kemajuan bangsa.

Lembaga pendidikan Islam dituntut untuk mendesain model-model pendidikan yang sesuai dengan kebutuhan perkembangan sekarang ini. Namun timbul pertanyaan tentang model pendidikan Islam yang bagaimana yang diharapkan dapat menghadapi dan menjawab tantangan perubahan yang terjadi dalam kehidupan masyarakat. Lembaga pendidikan Islam di Indonesia menurut Muhaimin dapat dikelompokkan ke dalam lima jenis, yaitu

a. Pondok Pesantren atau Madrasah Diniyah, menurut UU No. 20 Tahun 2003 tentang Sistem Pendidikan Nasional disebut sebagai pendidikan keagamaan (Islam) formal.

b. Madrasah dan pendidikan lanjutannya seperti IAIN/STAIN atau UIN yang bernaung di bawah Departemen Agama

c. Pendidikan usia dini/TK, Sekolah/Perguruan Tinggi yang diselenggarakan oleh dan atau berada di bawah naungan yayasan dan organisasi Islam.

d. Pelajaran agama Islam di Sekolah/Madrasah/Perguruan Tinggi sebagai suatu mata pelajaran atau mata kuliah dan atau sebagai program studi

e. Pendidikan Islam dalam keluarga atau di tempat-tempat ibadah, forum - forum kain ke-Islam-an, majelis taklim, dan institusi-institusi lainnya. ${ }^{2}$

${ }^{1}$ Hoedi Prasetyo dan Wahyudi Sutopo, Industri 4.0: Telaah Klasifikasi Aspek dan Arab Perkembangan Riset , Jti UNDIP: Jurnal Teknik Industri, Vol. 13, No. 1, Januari 2018, hlm. 19.

2 Muhaimin, Pemikiran dan Aktualisasi Pengembangan Pendidikan Islam (Jakarta: PT Raja Grafindo Persada, 2011), hlm. 39-40. 
Nur Rohmah Hayati

Pesantren merupakan salah satu jenis pendidikan yang berkembang di Indonesia. Perkembangan dari masa ke masa pesantren di Indonesia sudah banyak dilakukan para kyai yang ingin merespon ketertinggalan pendidikan yang berjalan di pesantren. Pemerintah juga sudah mendorong dengan berbagai kebijakan untuk memajukan pesantren. Pesantren harus memperkuat ke dalam berbagai aspek. Mulai kurikulum, sistem, manajemen, model, strategi, dan pendekatan pembelajaran dengan penguatan keterampilan abad 21 . Pengembangan pesantre dalam berbagai aspek merupakan salah satu solusi yang dapat digunakan untuk meningkatkan kualitas atau mutu pesantren.

\section{B. Pesantren dan Perkembangannya}

'Sejarah awal berdirinya, pesantren mengkonsentrasikan diri pada tiga fungsi utamanya yaitu mengajarkan atau menyebar luaskan ajaran Islam, mencetak para ulama, menanamkan tadisi Islam dalam masyarakat. ${ }^{3}$ Dari sisi Kurikulum dalam pesantren sampai awal abad ke 20 belum digunakan. Dengan kata lain, sistem pembelajaran lebih ditekankan pada pemahaman kitab secara apa adanya, dan memberikan pembedaan arahan pembelajaran dan pendidikan hanya didasarkan pada kategorisasi perbedaan kitab semata. ${ }^{4}$ Sebelum masuknya sistem madrasah bakat dan kemampuan santri di pesantren tidak mendapatkan perhatian dari kyai dan pembantunya. ${ }^{5}$ Selanjutnya sebagaimana kita ketahui bahwa akhirakhir ini hampir semua pesantren telah mengubah dan mengembangkan dirinya dengan memiliki madrasah, akan tetapi memiliki madrasah saja untuk saat ini masih kurang karena perkembangan teknologi diluar pesantren, tuntutan kemampuan hard skill dan soft skill santri juga sangatlah pesat. Santri bukan hanya dituntut menguasai penguasaan agama saja, akan tetapi pengembangan untuk pekerjaan ketika keluar dari pesantren.

Pondok pesantren secara garis besar dapat dikelompokkan, sebagaimana dituangkan dalam PMA No.3 Tahun 1979 yang mengkategorikan pondok pesantren menjadi :

a. Pondok pesatren tipe A yaitu pondok pesantren yang seluruhnya dilaksanakan secara tradisional.

3 Abudin Nata, Sejarah Sosial Intelektual Islam dan Institusi Pendidikannya, (Jakarta: PT Raja Grafindo Persada, 2012), hlm. 321.

${ }^{4}$ Abdur Rahman Asegaf, Pendidikan Islam di Indoonesia, ( Yogyakarta: Suka Press, 2007), hlm. 91.

${ }^{5}$ Suismanto, Menelusuri Jejak Pesantren, (Yogyakarta: Alif press, 2004), hlm.66 
b. Pondok pesantren tipe B yaitu pondok yang menyelenggarakan pengajaran secara klasikal.

c. Pondok pesantren tipe $\mathrm{C}$ yaitu pondok pesantren yang hanya merupakan asrama sedangkan santrinya belajar diluar.

d. Pondok pesantren tipe D yaitu pondok pesantren yang menyelenggarakan sistem pondok pesantren dan sekaligus sistem sekolah atau madrasah. ${ }^{6}$

Secara faktual ada beberapa tipe pondok pesantren yang berkembang dalam masyarakat, yang meliputi:

a. Pondok pesantren tradisional

Salaf artinya lama, dahulu, atau tradisional. Pondok pesantren salafiyah adalah pondok pesantren yang menyelenggarakan pembelajaran dengan pendekatan tradisional, sebagaimana yang berlangsung sejak awal pertumbuhannya. ${ }^{7}$ Pondok pesantren ini masih tetap mempertahankan bentuk aslinya dengan semata-mata mengajarkan kitab yang ditulis oleh ulama abad 15 dengan menggunakan bahasa Arab.

b. Pondok pesantren modern(khalafiyah/'Ashriyah)

Khalaf artinya kemudian, sedangkan ashri artinya sekarang atau modern. Pondok tipe ini adalahpengembangan pondok pesantren tradisional, karena orientasinya belajar cenderung mengadopsi sistem belajar klasik dan meninggalkan sistem belajar tradisional.

c. Pondok pesantren komprehensif/campuran

Pondok pesantren ini disebut komprehensif karena merupakan sistem pendidikan dan pengajaran gabungan antara tradisional dan yang modern. Artinya didalamnya diterapkan pendidikan dan pengajaran kitab kuning dengan metode sorogan, bandongan dan wetonan, namun secara regular sistem persekolahan terus

6 DEPAG RI DIRJEN Kelembagaan Agama Islam, Pondok Pesantren dan Madrasah Diniyah Pertumbuban dan Perkembangannya (Jakarta: DEPAG RI, 2003), hlm. 15.

7 DEPAG RI DIRJEN Kelembagaan Agama Islam, Pondok Pesantren dan Madrasab Diniyah Pertumbuban dan Perkembangannya..., hlm. 29. 
Nur Rohmah Hayati

dikembangkan. ${ }^{8}$ Perkembangan pesantren saat ini diharapkan dapat menumbuhkan atau bertambahnya pesantren yang berwawasan global, sehingga pesantren menjadi sebuah lembaga pendidikan Islam yang mampu beradaptasi dalam menhadapi arus revolusi industri tanpa kehilangan jati diri, tetap memproduksi santri yang berakhlak baik dan mampu berkiprah di dunia global.

Realitas pendidikan Islam dalam arti pesantren saat ini bisa dibilang stagnan tak ada perubahan yang cukup signifikan dari waktu ke waktu. Di antara indikasinya adalah, Pertama, minimnya upaya pembaharuan. Kedua, praktik pendidikan Islam sejauh ini masih memelihara warisan yang lama, dan tidak banyak melakukan pemikiran kreatif, inovatif, dan kritis terhadap isu-isu aktual. Ketiga, model pembelajaran pendidikan Islam terlalu menekankan pada pendekatan intelektualisme-verbalistik dan menegasikan pentingnya interaksi edukatif dan komunikatif antara guru-murid. Keempat orientasi pendidikan Islam menitikberatkan pada pembentukan hamba Allah dan tidak seimbang dengan pencapaian karakter manusia muslim sebagai Khalifah fi al-Ardl. ${ }^{9}$ Implikasi dari realitas tersebut adalah terpasungnya kreatifitas santri. Pendidikan menjadi tercerabut dari esensinya. Pendidikan semestinya merupakan upaya memerdekakan manusia dari belenggu kebodohan melalui cara yang humanistik yang menghargai potensi-potensi yang dimiliki peserta didik serta menjadikannya sebagai modal dasar dalam menciptakan santri yang mampu menghadapi dunia luar pesantren.

\section{Pesantren dalam Era 4.0}

Istilah 'Revolusi Industri' diperkenalkan oleh Friedrich Engels dan LouisAuguste Blanqui di pertengahan abad ke-19. Revolusi industri ini pun sedang berjalan dari masa ke masa. Dekade terakhir ini sudah dapat disebut memasuki fase keempat 4.0. Perubahan fase ke fase memberi perbedaan artikulatif pada sisi kegunaaannya. Fase pertama (1.0) bertempuh pada penemuan mesin yang menitikberatkan (stressing) pada mekanisasi produksi. Fase kedua (2.0) sudah beranjak

${ }^{8}$ Muwahid Shulhan, Manajemen Pendidikan Islam, (Yogyakarta: Teras, 2013), hlm. 155-157.

${ }^{9}$ Imam Machali, Pendidikan Islam dan Tantangan Globalisasi, (Yogyakarta: Presma dan Ar-Ruzz Media, 2004), hlm. 8-9. 
pada etape produksi massal yang terintegrasi dengan quality control dan standarisasi. Fase ketiga (3.0) memasuki tahapan keseragaman secara massal yang bertumpu pada integrasi komputerisasi. Fase keempat (4.0) telah menghadirkan digitalisasi danotomatisasi perpaduan internet dengan manufaktur. ${ }^{10}$

Era Revolusi Industri 4.0 (selanjutnya: Era 4.0) membawa dampak yang tidak sederhana. Ia berdampak pada seluruh aspek kehidupan manusia. Termasuk dalam hal ini adalah pendidikan. Era ini ditandai dengan semakin sentralnya peran teknologi yyber dalam kehidupan manusia. Maka tak heran jika dalam dunia pendidikan muncul istilah "Pendidikan 4.0". Pendidikan 4.0 (Education 4.0) adalah istilah umum digunakan oleh para ahli pendidikan untuk menggambarkan berbagai cara untuk mngintegrasikan teknologi cyber baik secara fisik maupun tidak ke dalam pembelajaran. Ini adalah lompatan dari pendidikan 3.0 yang menurut Jeff Borden mencakup pertemuan ilmu saraf, psikologi kognitif, dan teknologi pendidikan Pendidikan 4.0 adalah fenomena yang merespons kebutuhan munculnya revolusi industri keempat di mana manusia dan mesin berkolaborasi ${ }^{11}$

Merujuk hasil penelitian dari McKinsey pada 2016 bahwa dampak dari digital technology menuju revolusi industri 4.0 dalam lima (5) tahun kedepan akan ada 52,6 juta jenis pekerjaan akan mengalami pergeseran atau hilang dari muka bumi. Hasil penelitian ini memberikan pesan bahwa setiap diri yang masih ingin mempunyai eksistensi diri dalam kompetisi global harus mempersiapkan mental dan skill yang mempunyai keunggulan persaingan (competitive advantage) dari lainnya. Jalan utama mempersiapkan skill yang paling mudah ditempuh adalah mempunyai perilaku yang baik (behavioral attitude), menaikan kompetensi diri dan memiliki semangat literasi. Bekal persiapan diri tersebut dapat dilalui dengan jalur pendidikan (long life education) dan konsep

${ }^{10}$ Hendra Suwardana, Revolusi Industri 4. 0 Berbasis Revolusi Mental, JATI UNIK, Vol.1, No.2, 2017, hlm. 102-110. Januari 2019.

11 http://e-jurnal.unisda.ac.id/index.php/talim/article/view/948/531 diakses pada tanggal 25 
Nur Rohmah Hayati

diri melalui pengalaman bekerjasama lintas generasi/lintas disiplin ilmu (experience is the best teacher). ${ }^{12}$

Tantangan era Revolusi Industri 4.0 kompleks sekali. Belum lagi di dunia pendidikan, semua sudah berkonversi di dunia digital. Jika dulu cukup sistem manual, kuno, primitif, saat ini semua harus serba siber. Contohkan e-library (perpustakaan digital), elearning (pembelajaran digital), e-book (buku online), dan lainnya. ${ }^{13}$ Dari penjelasan di atas, dapat disimpulkan tantangan era Revolusi Industri 4.0 sangat komplek. Pertama, keamanan teknologi informasi yang menyasar ke dunai pendidikan. Kedua, keandalan dan stabilitas mesin produksi. Ketiga, kurangnya keterampilan yang memadai. Keempat, keengganan untuk berubah para pemangku kepentingan. Kelima, hilangnya banyak pekerjaan karena otomatisasi. Keenam, stagnasi pemanfaatan teknologi, informasi, dan komunikasi. Ketujuh, belum meratanya perubahan kurikulum, model, strategi, pendekatan dan guru dalam pembelajaran yang menguatkan literasi baru. Perkembangan era Revolusi Industri 4.0 yang ditandai dengan masifnya perkembangan digital technology, artificial intelligence, big data, robotic, dan lainnya menjadi proyek bersama semua lembaga pendidikan untuk menjawabnya. ${ }^{14}$

Walaupun sekarang memasuki dunia global namun sudah menjadi common sense bahwa pesantren dekat dengan figur Kiai. Masih banyak kyai yang anti dengan perubahan dunia global. Dalam manajemen pesantren Kyai adalah figur sentral, otoritatif, dan pusat seluruh kebijakan dan perubahan. Hal ini karena dua faktor utama yaitu: pertama, kepemimpinan yang tersentralisasi pada individu yang bersandar pada karisma serta hubungan yang bersifat patrenalistik. Kebanyakan pesantren menganut sistem serba mono: mono manajemen dan mono administrasi sehingga tidak ada delegasi kewenangan ke unit-unit kerja yang ada dalam organisasi. Kedua, kepemilikan pesantren yang bersifat individual(atau keluarga) bukan komunal. ${ }^{15}$ Januari 2019.

12 http://e-jurnal.unisda.ac.id/index.php/talim/article/view/948/531 diakses pada tanggal 25 8

${ }^{13}$ Dian Marta Wijayanti, Guru Zaman Now (Guruku, Sahabatku), (Semarang: Formaci, 2017), hlm. 7-

14 http://www.jurnaliainpontianak.or.id/index.php/jrtie/article/view/1064 diakses pada tanggal 25 Januari 2019.

15 Sulthon Masyhud, Manajemen Pondok Pesantren(Jakarta: Diva Pustaka, 2005), hlm. 14-15. 
Kiai menguasai dan mengendalikan seluruh sector kehidupan pesantren. Kedudukan Kiai adalah kedudukan ganda: sebagai pengasuh sekaligus pemilik pesantren. Kekuasaan mutlak itu pada gilirannya menyuburkan variasi pesantren, berbagai bentuk dan corak pesantren merupakan akibat dari kebijaksanaan Kiai yang berbeda-beda dan tidak pernah diseragamkan. ${ }^{16}$ Ditambah pesantren terpolarisasikan ketika menghadapkan zaman, ada pesantren yang bersikap lunak dan ada yang keras. Ada pesantren yang terbuka, dan ada yang tertutup. ${ }^{17}$ Sehingga membuat pesantren kenyataan di lapangan juga bermacammacam bentuknya.

1. Pesantren tradisional

Dalam manajemen pesantren tradisional. Kiai menjadikan pesantren seolaholah eksklusif, terasing dari kehidupan luar dan didukung kehidupannya yang unik. Umumnya beberapa pesantren tradisional berada di daerah peripheral yang jauh dari budaya urban. Dibeberapa pesantren Kiai mengharamkan mata pelajaran umum, tidak ada yang berani menyangkal apalagi sampai menggoyahkan keputusan ini. ${ }^{18}$ Kondisi ini yang menyebabkan orang luar tidak boleh dan merasa tidak memiliki hak untuk mengajukan usulan-usulan kosntruktif-strategik dalam upaya pengembangan pesantren dimasa depan, pihak Kiai sendiri tidak membuka ruang bagi pemikiran-pemikiran dari luar yang menyangkut penentan dari kebijakan pesantren. ${ }^{19}$ Pembelajaran ilmu-ilmu agama Islam dilakukan secara individu atau kelompok dengan konsentrasi pada kitab-kitab klasik berbahasa Arab. Perjenjangan tidak didasarkan pada satuan waktu, tetapi berdasarkan tamatnya kitab yang dipelajari. Dengan selesainya satu kitab tertentu santri dapat naik jenjang dengan mempelajari kitab yang tingkat kesukarannya lebih tinggi. ${ }^{20}$ Alamsyah Ratu Prawiranegara juga mengemukakan beberapa pola umum yang khas yang terdapat dalam pendidikan Islam tradisional diantaranya sebagai berikut: pertama, Independen. Kedua, kepemimpinan tunggal. Ketiga, kebersamaan yang

\footnotetext{
${ }^{16}$ Mujamil Qomar, Pesantren dari Transformasi Metodologi Menuju Demokratisasi Intitusi, (Jakarta: Erlangga, 2008), hlm. 31-32.

${ }^{17}$ Mujamil Qomar, Pesantren dari Transformasi Metodologi Menuju Demokratisasi Intitusi...., hlm.77.

${ }^{18}$ Mujamil Qomar, Pesantren dari Transformasi Metodologi Menuju Demokratisasi Intitusi...., hlm. 35-36.

${ }^{19}$ Mujamil Qomar, Pesantren dari Transformasi Metodologi Menuju Demokratisasi Intitusi...., hlm. 40.

${ }^{20}$ DEPAG RI DIRJEN Kelembagaan Agama Islam, Pondok Pesantren..., hlm. 29-30.
} 
Nur Rohmah Hayati

merefleksikan kerukunan. Keempat, kegotong-royongan. Kelima, motivasi yang terarah dan pada umumnya mengarah pada peningkatan hidup beragama. ${ }^{21}$

2. Pesantren Modern

Pondok pesantren ini adalah pondok pesantren yang menyelenggarakan kegiatan pendidikan dengan pendekatan modern, melalui satuan pendidikan formal baik madrasah maupun sekolah. Pembelajaran pondok pesantren khalafiyah dilakukan secara berjenjang dan berkesinambungan dengan satuan program didasarkan pada satuan waktu, seperti semester, catur wulan. ${ }^{22}$ Dalam pondok pesantren modern kedudukan para kyai adalah sebagai koordinator pelaksana proses belajar-mengajar dan sebagai pengajar langsung dikelas.

3. Pesantren Komprehensif

Pondok pesantren ini disebut komprehensif karena merupakan sistem pendidikan dan pengajaran gabungan antara tradisional dan yang modern. Pondok pesantren ini sebagaimana pondok pesantren modern, hanya saja lembaga pendidikannya lebih lengkap. Terutama dalam bidang ketrampilan dan benar-benar memperhatikan kualitasnya tetapi tidak menggeser cirri khusus kepesantrenannya yang masih relevan dengan kebutuhan masyarakat dan zaman. ${ }^{23}$ Pesantren yang tertutup tentu tidak menerima perubahan, padahal ketika pesantren menolak pesatnya perubahan itu mempersulit santri ketika lulus dari pesantren dan menghadapi dunia diluar pesantren

Ciri masyarakat masa depan itu antara lain pertama globalisasi. Kedua, perkembangan IPTEK yang makin cepat. Ketiga Arus komunikasi yang semakin padat dan cepat yang merubah masyarakat menjadi masyarakat informasi. Keempat Peningkatan layanan profesional dalam berbagai segi kehidupan bangsa. ${ }^{24}$ Ciri masyarakat masa depan tersebut harus dijawab pesantren dikarenakan perubahan di luar pesantren begiti pesatnya. Revolusi telah terjadi sepanjang sejarah ketika teknologi baru dan cara baru untuk memahami dunia memicu perubahan besar dalam sistem ekonomi dan struktur social. Revitalisasi sistem

${ }^{21}$ Amin Haedari, Masa Depan Pesantren (Jakarta: IRD Press, 2004), hlm. 15.

22 DEPAG RI DIRJEN Kelembagaan Agama Islam, Pondok Pesantren..., hlm. 30.

${ }^{23}$ Ridlwan Nasir, Mencari Tipologi Format Pendidikan Ideal..., hlm. 88.

24 Umar Tirtarahardja, Pengantar Pendidikan, (Jakarta: DIKTI DEPDIKBUD, 1994), hlm. 157.

170 ๑2019 Islamic Review: Jurnal Riset dan Kajian Keislaman 
pembelajaran meliputi penguatan kualitas kurikulum dan pendidikan karakter, bahan pembelajaran berbasis teknologi informasikomunikasi, kewirausahaan, penyelarasan dan evaluasi. Revitalisasi harus menyentuh kualitas, peningkatan kualitas lulusan atau santri sendiri, peningkatan kemampuan manajerial pengelola, kemampuan ustad atau ustadzah, dan peningkatan sarana prasarana. Ada enam prinsip desain Industri 4.0, mulai dari interoperability, virtualisasi, desentralisasi, kemampuan real time, berorientasi layanan dan bersifat modular. Revolusi Industri 4.0 dapat diartikan sebagai era industri, di mana seluruh entitas di dalamnya dapat saling berkomunikasi secara real time kapan saja dengan berlandaskan pemanfaatan teknologi internet dan CPS guna mencapai tujuan tercapainya kreasi nilai baru ataupun optimasi nilai yang sudah ada dari setiap proses di industri. ${ }^{25}$

Dari penjelasan di atas, dapat disimpulkan tantangan era Revolusi Industri 4.0 sangat komplek. Pertama, keamanan teknologi informasi yang menyasar ke dunai pendidikan. Kedua, keandalan dan stabilitas mesin produksi. Ketiga, kurangnya keterampilan yang memadai. Keempat, keengganan untuk berubah para pemangku kepentingan. Kelima, hilangnya banyak pekerjaan karena otomatisasi. Keenam, stagnasi pemanfaatan teknologi, informasi, dan komunikasi. Ketujuh, belum meratanya perubahan kurikulum, model, strategi, pendekatan dan guru dalam pembelajaran yang menguatkan literasi baru. Perkembangan era Revolusi Industri 4.0 yang ditandai dengan masifnya perkembangan digital technology, artificial intelligence, big data, robotic, dan lainnya menjadi proyek bersama semua lembaga pendidikan untuk menjawabnya. Meskipun tidak bisa pada semua aspek, minimal lembaga pendidikan tingkat dasar fokus pada penguatan sistem baru. ${ }^{26}$ Pesantren harus bertransformasi dengan merubah diri menjadi pesantren digital, digital kitab, pesantren yang memberikan pengajian jarak jauh dengan memanfaatkan teknologi seperti e-learning.

\section{Penutup}

${ }^{25}$ Hoedi Prasetyo dan Wahyudi Sutopo, Industri 4.0: Telaab Klasifikasi Aspek dan Arah Perkembangan Riset , Jti Undip: Jurnal Teknik Industri, Vol. 13, No. 1, Januari 2018, hlm. 1. 2018, hal 7-8.

${ }^{26}$ Hamidullah Ibda, JRTIE: Journal of Research and Thought of Islamic Education Vol. 1, No. 1, 
Nur Rohmah Hayati

Pesantren merupakan salah satu jenis pendidikan yang berkembang di Indonesia. Perkembangan dari masa ke masa pesantren di Indonesia sudah banyak dilakukan para kyai yang ingin merespon ketertinggalan pendidikan yang berjalan di pesantren. Pemerintah juga sudah mendorong dengan berbagai kebijakan untuk memajukan pesantren. Pesantren harus memperkuat ke dalam berbagai aspek. Mulai kurikulum, sistem, manajemen, model, strategi, dan pendekatan pembelajaran dengan penguatan keterampilan abad 21.

Realitas pendidikan Islam dalam arti pesantren saat ini bisa dibilang stagnan tak ada perubahan yang cukup signifikan dari waktu ke waktu. Di antara indikasinya adalah, Pertama, minimnya upaya pembaharuan. Kedua, praktik pendidikan Islam sejauh ini masih memelihara warisan yang lama, dan tidak banyak melakukan pemikiran kreatif, inovatif, dan kritis terhadap isu-isu aktual. Ketiga, model pembelajaran pendidikan Islam terlalu menekankan pada pendekatan intelektualisme-verbalistik dan menegasikan pentingnya interaksi edukatif dan komunikatif antara guru-murid. Keempat orientasi pendidikan Islam menitikberatkan pada pembentukan hamba Allah dan tidak seimbang dengan pencapaian karakter manusia muslim sebagai Khalifah Fi Al-Ardl.

Era Revolusi Industri 4.0 (selanjutnya: Era 4.0) membawa dampak yang tidak sederhana. Ia berdampak pada seluruh aspek kehidupan manusia. Termasuk dalam hal ini adalah pendidikan. Era ini ditandai dengan semakin sentralnya peran teknologi cyber dalam kehidupan manusia. Maka tak heran jika dalam dunia pendidikan muncul istilah 'Pendidikan 4.0'. Pendidikan 4.0 (Education 4.0) adalah istilah umum digunakan oleh para ahli pendidikan untuk menggambarkan berbagai cara untuk mngintegrasikan teknologi cyberbaik secara fisik maupun tidak ke dalam pembelajaran. Ini adalah lompatan dari pendidikan 3.0 yang menurut Jeff Borden mencakup pertemuan ilmu saraf, psikologi kognitif, dan teknologi pendidikan Pendidikan 4.0 adalah fenomena yang merespons kebutuhan munculnya revolusi industri keempat di mana manusia dan mesin disimpulkan tantangan era Revolusi Industri 4.0 sangat kompleks. Pertama, keamanan teknologi informasi yang menyasar ke dunai pendidikan. Kedua, keandalan dan stabilitas mesin produksi. 
Ketiga, kurangnya keterampilan yang memadai. Keempat, keengganan untuk berubah para pemangku kepentingan. Kelima, hilangnya banyak pekerjaan karena otomatisasi. Keenam, stagnasi pemanfaatan teknologi, informasi, dan komunikasi. Ketujuh, belum meratanya perubahan kurikulum, model, strategi, pendekatan dan guru dalam pembelajaran yang menguatkan literasi baru. Perkembangan era Revolusi Industri 4.0 yang ditandai dengan masifnya perkembangan digital technology, artificial intelligence, big data, robotic, dan lainnya menjadi proyek bersama semua lembaga pendidikan untuk menjawabnya. Meskipun tidak bisa pada semua aspek, minimal lembaga pendidikan tingkat dasar fokus pada penguatan system baru. Pesantren harus bertransformasi dengan merubah diri menjadi pesantren digital, digital kitab, pesantren yang memberikan pengajian jarak jauh dengan memanfaatkan teknologi seperti e-learning. 
Nur Rohmah Hayati

\section{Daftar Pustaka}

Asegaf, Abdur Rahman, 2007. Pendidikan Islam di Indoonesia. Yogyakarta: Suka Press.

DEPAG RI DIRJEN Kelembagaan Agama Islam, 2003. Pondok Pesantren dan Madrasah Diniyah Pertumbuban dan Perkembangannya. Jakarta: DEPAG RI.

http://e-jurnal.unisda.ac.id/index.php/talim/article/view/948/531 diakses pada tanggal 25 Januari 2019

http://www.jurnaliainpontianak.or.id/index.php/jrtie/article/view/1064 diakses pada tanggal 25 Januari 2019

Imam Machali, 2004. Pendidikan Islam dan Tantangan Globalisasi. Yogyakarta: Presma dan ArRuzz Media.

Masyhud, Sulthon, 2005. Manajemen Pondok Pesantren. Jakarta: Diva Pustaka.

Muhaimin, 2011. Pemikiran dan Aktualisasi Pengembangan Pendidikan Islam, Jakarta: PT Raja Grafindo Persada.

Nata, Abudin, 2012. Sejarah Sosial Intelektual Islam dan Institusi Pendidikannya.Jakarta: PT Raja Grafindo Persada.

Prasetyo, Hoedi dan Wahyudi Sutopo, 2018. Industri 4.0: Telaah Klasifikasi Aspek dan Arah Perkembangan Riset, Jti Undip: Jurnal Teknik Industri, Vol. 13, No. 1.

Qomar, Mujamil, 2008. Pesantren dari Transformasi Metodologi Menuju Demokratisasi Intitusi, Jakarta: Erlangga.

Shulhan, Muwahid, 2013. Manajemen Pendidikan Islam. Yogyakarta: Teras.

Suismanto, 2004. Menelusuri Jejak Pesantren. Yogyakarta: Alif press.

Suwardana, Hendra, 2017. Revolusi Industri 4. O Berbasis Revolusi Mental, JATI UNIK Vol.1, No.2.

Tirtarahardja, Umar, 1994. Pengantar Pendidikan. Jakarta: DIKTI DEPDIKBUD.

Wijayanti, Dian Marta, 2017.Guru Zaman Now (Guruku, Sahabatku),Semarang: Formaci. 